\title{
Top-down regulation in ctenophore-copepod- ciliate-diatom-phytoflagellate communities in coastal waters: a mesocosm study
}

\author{
Edna Granéli ${ }^{1, *}$, Jefferson T. Turner ${ }^{2}$ \\ ${ }^{1}$ Department of Marine Sciences, University of Kalmar, 39182 Kalmar, Sweden \\ ${ }^{2}$ Biology Department and School for Marine Science and Technology, University of Massachusetts, Dartmouth, \\ North Dartmouth, Massachusetts 02747, USA
}

\begin{abstract}
Interactions between the ctenophore Pleurobrachia pileus, copepods, ciliates and phytoplankton in a late spring natural plankton community were studied experimentally using mesocosms consisting of $300 \mathrm{l}$ polyethene cylinders. Mesocosms were filled with $90 \mu \mathrm{m}$ filtered nutrient-enriched seawater from Gullmar Fjord on the Swedish Skagerrak coast. Mesozooplankton (primarily copepods and marine cladocerans) or ctenophores were added, either alone or in combination, to examine topdown predation and grazing effects on phytoplankton abundance and composition. Predation impact of ctenophores on copepods appeared to be minimal in that it did not significantly decrease the biomass of the copepods until the last day of the experiment. However, in the presence of ctenophores, ciliates increased compared to controls both with and without added zooplankton, suggesting that ctenophore predation on copepods reduced copepod predation on ciliates. In the absence of ctenophores, ciliates declined precipitously, presumably due to copepod predation. This was particularly severe in treatments with zooplankton added at $10 \times$ the natural abundance but without ctenophores. Copepods heavily grazed on the diatom Skeletonema costatum, and most phytoflagellates increased in mesocosms with copepod additions, suggesting that they were not substantially grazed by copepods. However, copepods did graze to some extent on larger dinoflagellates of the genus Gymnodinium/Karenia. Ciliates were important phytoplankton grazers, especially of phytoflagellates and picoplankton. It appears that the primary top-down effect of ctenophore predation on copepods was to reduce copepod predation on ciliates, thereby increasing ciliate grazing on the small flagellates that dominated the phytoplankton.
\end{abstract}

KEY WORDS: Ctenophore $\cdot$ Copepod $\cdot$ Ciliate $\cdot$ Diatom $\cdot$ Flagellate $\cdot$ Predation $\cdot$ Marine ecosystem $\cdot$ Mesocosm Resale or republication not permitted without written consent of the publisher

\section{INTRODUCTION}

There is extensive literature on top-down control of phytoplankton by predation-induced trophic cascades in freshwater ecosystems (reviewed by Carpenter et al. 1985, Carpenter 1988) whereby predation on herbivorous zooplankton leads to increases in phytoplankton. Such studies are less numerous in marine ecosystems,

*E-mail: edna.graneli@hik.se but there are suggestions that predation on copepods by gelatinous predators such as scyphomedusae and ctenophores may decrease copepod grazing pressure, and increase the biomass or alter species composition of phytoplankton (Deason 1982, Deason \& Smayda 1982, Turner et al. 1983, Greve \& Reiners 1988, Olsson et al. 1992, Granéli et al. 1993, French \& Smayda 1995).

There are conflicting data on the importance of jellyfish and ctenophore predation on copepods. Inverse field abundances of copepods and the scyphomedusa Aurelia aurita (Möller 1980, Schneider \& Behrends 
1998) and between copepods and ctenophores of the genera Mnemiopsis and Pleurobrachia (reviewed by Reeve \& Walter 1978, Kremer 1979, Frank 1986) suggest that the predation impact of gelatinous carnivores on copepods can be high. In contrast, there are indications of a relatively small predatory impact of Pleurobrachia pileus on copepods in European coastal waters (Miller \& Daan 1989, Kuipers et al. 1990, Båmstedt 1998).

Selective grazing by mesozooplankton such as copepods may change phytoplankton species composition. Selective copepod grazing on diatoms (Turner \& Tester 1989) could reduce grazing pressure on phytoflagellates and other non-diatom phytoplankters (Granéli et al. 1989). This could possibly contribute to events such as the ichthyotoxic Scandinavian bloom of Chrysochromulina polylepis, which began in the Skagerrak in late spring of 1988 (Dahl et al. 1989). Alternatively, if ctenophore predation removes copepods, this could contribute to blooms of phytoplankters normally grazed by copepods.

The present study was designed to use a land-based large mesocosm system to investigate whether manipulations of ctenophore and mesozooplankton abundance could change the phytoplankton biomass and species composition of a natural late spring (post-bloom) phytoplankton community from a coastal area of the Skagerrak. Our hypothesis was that ctenophore predation might affect phytoplankton biomass and species composition by reducing copepod abundance, leaving ungrazed phytoflagellates to bloom. Such changes at higher trophic levels have been suggested to contribute to phytoflagellate blooms in Skagerrak coastal waters, particularly in Gullmar Fjord (Lindahl \& Hernroth 1983, 1988). Additional grazing experiments with copepods and marine cladocerans (Turner \& Granéli 1992) were performed in parallel with the mesocosm studies presented here.

\section{MATERIALS AND METHODS}

From 17 to 24 May 1990, a mesocosm experiment was performed at the Kristineberg Marine Biological Laboratory on Gullmar Fjord, on the Swedish west coast (SE Skagerrak). Mesocosms consisted of 3001 polyethene cylinders filled with $90 \mu \mathrm{m}$ mesh-filtered seawater $(17 \%)$ pumped from $2 \mathrm{~m}$ depth and $50 \mathrm{~m}$ offshore from the laboratory dock. The water was pumped into the cylinders in $10 \mathrm{~s}$ intervals for each cylinder (approximately 50 l) sequentially, until the cylinders were filled, in order to achieve uniformly mixed phytoplankton suspensions in cylinders. The cylinders were placed in a larger plastic pool on the laboratory dock, through which surface seawater was continuously pumped to maintain in situ temperature. The temperature difference between the fjord surface water and the cylinders was never more than $1.0^{\circ} \mathrm{C}$. The temperature in the cylinders varied between 11.5 and $13.4^{\circ} \mathrm{C}$ throughout the experimental period. Mesocosms were covered with translucent white plastic covers and exposed to natural sunlight.

The experimental design was as follows, and included 3 replicates of each treatment:

- Control (C): natural phytoplankton and natural zooplankton abundance;

- Zooplankton (Z): natural phytoplankton plus $10 \times$ the natural zooplankton abundance;

- Ctenophores (Ct): 10 ctenophores (Pleurobrachia pileus), approximately $2 \mathrm{~cm}$ in diameter, plus phytoplankton and zooplankton at natural abundance;

- A combination of the $\mathrm{Z}$ and Ct cylinders (CtZ): 10 ctenophores, plus $10 \times$ the natural zooplankton abundance and natural phytoplankton abundance

Since one of the aims of this study was to investigate zooplankton grazing pressure on various components of the phytoplankton community, we added natural zooplankton abundances to $\mathrm{C}$ and $\mathrm{Ct}$ treatments, and $10 \times$ the natural zooplankton abundances to the $\mathrm{Z}$ and $\mathrm{CtZ}$ cylinders. To achieve natural and $10 \times$ natural zooplankton abundance, zooplankton were caught with a $90 \mu \mathrm{m}$ plankton net towed horizontally at a depth of about $2 \mathrm{~m}$ in the fjord. Zooplankton were left for $24 \mathrm{~h}$ with aeration in two $20 \mathrm{l}$ carboys, at the ambient fjord temperature $\left(11^{\circ} \mathrm{C}\right)$, to allow dead and injured animals to sink to the bottoms of the carboys. Animals on the bottom or floating on the surface (primarily Evadne nordmani) were removed through siphoning before subsampling of actively swimming animals for abundance estimates, followed by addition to the cylinders. Water (30 l) was collected at the towing site to estimate the natural zooplankton abundance. On the basis of this value, appropriate additions were made to the mesocosm cylinders from the concentrated zooplankton in the carboy samples. In order to treat all zooplankton in the same manner, even the cylinders containing natural zooplankton abundances $(\mathrm{C}$ and $\mathrm{Ct}$ ) were subjected to the same procedure, i.e. the water was screened through a $90 \mu \mathrm{m}$ net, and natural zooplankton abundances were subsequently added back to these cylinders. Otherwise, zooplankton in the $\mathrm{Z}$ and CtZ treatments might have had more handling than zooplankton in the $\mathrm{C}$ and $\mathrm{Ct}$ treatments. Since seawater was screened through a $90 \mu \mathrm{m}$ net, undoubtedly some microzooplankton, such as copepod nauplii and ciliates, slipped through the net. The phytoplankton species composition and biomass in the cylinders did not differ appreciably from in situ conditions, since few phytoplankton species larger than $90 \mu \mathrm{m}$ were present at the time of the experiment. 
Individuals of the ctenophore Pleurobrachia pileus were gently hand-dipped with a beaker from a boat rowed in the fjord and were placed in a carboy at in situ temperature for $24 \mathrm{~h}$. Ten active and healthy ctenophores, with approximate diameters of $2 \mathrm{~cm}$, were transferred with a beaker to each of the 6 cylinders. The experimental ctenophore abundance (33 ind. $\mathrm{m}^{-3}$ ) was within the natural abundance range found in the Gullmar Fjord during this period (L. Hernroth pers. comm.).

The initial nutrient concentrations (nitrate + nitrite, phosphate, ammonia and silicate) in the cylinders were measured, and nutrients were added daily to all cylinders to achieve the following concentrations: $10 \mu \mathrm{M}$ silicon, as $\mathrm{Na}_{2} \mathrm{SiF}_{6}$ (until the third day, when we found that silicon accumulated, so we decided to discontinue silicon additions); $3.2 \mu \mathrm{M}$ nitrogen, as $\mathrm{NH}_{4} \mathrm{Cl}_{\text {; }}$ and $0.2 \mu \mathrm{M}$ phosphorus, as $\mathrm{K}_{2} \mathrm{HPO}_{4}$. The atomic ratio of added nutrients was $50 \mathrm{Si} 16 \mathrm{~N}: 1 \mathrm{P}$, approximating Redfield ratios for nitrogen and phosphorus and an excess of silicon in order to avoid deficiency for the diatoms. Analyses of inorganic nutrients followed standard procedures for seawater analyses (UNESCO 1983). Nutrients were added to all cylinders in order to neutralize the fertilizing effects of zooplankton and ctenophore excretion in some cylinders but not others.

After gentle mixing of the cylinders by slowly lowering and raising a Secchi disc, samples were taken daily for analyses of inorganic nutrients (phosphate, ammonia, nitrate + nitrite, and silicate), in vivo chlorophyll $a$, phytoplankton, and ciliate and mesozooplankton species composition and abundance.

In vivo chlorophyll a fluorescence was measured on 3 fractions (total, $<20 \mu \mathrm{m}$ and $<3 \mu \mathrm{m}$ ) in a Turner 111 filter fluorometer. In vivo chlorophyll a fluorescence was transformed to chlorophyll $a$, after calibration with extracted chlorophyll a according to the method of Jeffrey \& Humphrey (1975) on water samples taken every $2 \mathrm{~d}$ and filtered through Whatmann GF/F glass fiber filters. Phytoplankton $>3 \mu \mathrm{m}$ was preserved in acidified Lugol's solution (1\% final concentration) and counted with an inverted microscope (Nikon TMD Diaphot) (Utermöhl 1958). The picoplankton (from the $<3 \mu \mathrm{m}$ fraction) was preserved in a filtered mixture of acridine orange and formalin (Coats \& Heinbokel 1982). Subsamples were filtered on black $0.2 \mu \mathrm{m}$ pore size Nuclepore filters and counted in a Zeiss epifluorescence light microscope, including both cyanobacteria and eukaryotes. Biomass as carbon was estimated from measurements of linear dimensions and a plasma volume:carbon factor of 0.11 for diatoms and 0.13 for dinoflagellates and other flagellates, as described by Edler (1979). Specific growth rates for phytoplankton, assuming exponential growth, were calculated according to the equation $\mu=\log _{2}\left(N_{t} / N_{0}\right) / t$, where $N_{t}$ is abun- dance in cells $\mathrm{ml}^{-1}$ at time $t(\mathrm{~d})$ and $N_{0}$ is the initial abundance.

One liter of sample was preserved in acidified Lugol's solution (1\% final conc.) for ciliate counts and size measurements. After $20 \mathrm{~h}$ the sample was carefully filtered on a $11 \mu \mathrm{m}$ net and rinsed down in $50 \mathrm{ml}$ flasks. A subsample was then counted in an inverted microscope using the Utermöhl (1958) method. Carbon biomass was estimated by measurements of linear dimensions and assuming a carbon:plasma volume ratio of $0.071 \times 10^{-6} \mu \mathrm{g} \mathrm{C} \mu \mathrm{m}^{-3}$ (Fenchel \& Finlay 1983). Specific growth rates of ciliates were calculated for each species, assuming exponential growth, using the same formula as for phytoplankton. In addition to daily estimates of ciliate biomass in the cylinders, potential and actual growth rates of ciliates were measured in $24 \mathrm{~h}$ incubations at the beginning of the experiment. The potential growth rates were measured as ciliate increases after removing all predators larger than $200 \mu \mathrm{m}$ in a water sample from the $\mathrm{C}$ group cylinders. Samples were incubated in $1 \mathrm{l}$ polycarbonate flasks for $24 \mathrm{~h}$ in the plastic pool. Actual growth rates were measured at the same time as increases in ciliates in flasks containing potential predators that had not been removed by screening through $200 \mu \mathrm{m}$ mesh.

Mesozooplankton samples (3 l) were concentrated on a $45 \mu \mathrm{m}$ mesh net, rinsed down into $100 \mathrm{ml}$ flasks and preserved in a $3 \%$ solution of borate-buffered formalin. The zooplankton were identified to species, counted and measured. About 200 specimens were measured in each sample. Length measurements were converted to dry weight by length-weight regressions for Oithona (Lampitt 1979), Acartia, Centropages, Pseudocalanus and Temora (Klein Breteler et al. 1982), and Evadne and Podon spp. (Kankaala \& Johanson 1986). Dry weight for the sum of all major copepod and cladoceran taxa was transformed to carbon using a factor of 0.4 (Hernroth 1985).

Ctenophores were sampled and their diameters were measured at the end of the experiment.

Treatment effects on ctenophore size were tested by the Mann-Whitney $U$-test except where specified otherwise.

In order to quantify the relationships between zooplankton and the different algal groups, we have analysed data using the following model of Lehman \& Sandgren (1985) with modifications as in Granéli et al. (1993):

$$
\begin{gathered}
\frac{\mathrm{d} A_{i}}{\mathrm{~d} t}=\mu_{i} A_{i}-\sum_{j} X_{i j} Z_{j} \\
\frac{\mathrm{d} Z_{j}}{\mathrm{~d} t}=\left(\alpha_{j} \sum_{i} X_{i j} K_{Z j}\right) Z_{j}-\sum_{k} X_{j k} Z_{k}, j \neq k
\end{gathered}
$$

where $A$ is phytoplankton biomass (as carbon, $\mu \mathrm{g} \mathrm{l}^{-1}$ ), $t$ is time (d), $Z$ is zooplankton biomass (as carbon, $\mu \mathrm{g}$ 
$\mathrm{l}^{-1}, \mathrm{Ct}$ as ind. $\left.\mathrm{l}^{-1}\right), X_{i j}$ is ingestion rate $\left(\mathrm{d}^{-1}\right)$ on $A_{i}$ (if grazing is dominant), $i, j$ and $k$ refer to different groups of organisms, $\mu$ is biomass specific growth rate $\left(\mathrm{d}^{-1}\right), K_{\mathrm{z}}$ is mortality $\left(\mathrm{d}^{-1}\right)$ and $\alpha$ is part of total prey that supports growth. $\mu$ is used in the meaning of growth rate for biomass including all losses that do not depend on grazing. If losses other than grazing can be neglected then $\mu$ is the intrinsic growth rate of the population.

$$
X=q A\left(\text { or } X_{i j}=q_{i j} A\right)
$$

where $q$ ( $1 \mathrm{\mu g} \mathrm{C}^{-1} \mathrm{~d}^{-1}$ algal or zooplankton specific) clearance rate is the equivalent 'volume' that is cleared to $100 \%$ per unit time $\left(\mathrm{d}^{-1}\right)$ and per unit zooplankton

$$
\begin{gathered}
\frac{\mathrm{d} A / \mathrm{d} t}{A_{j}}=\mu-\sum_{j} q_{i j} Z_{j} \\
\frac{\mathrm{d} Z_{j} / \mathrm{d} t}{Z_{j}}=\mu_{\text {ciliates }}-\sum_{k} q_{j k} Z_{k}, k \neq j
\end{gathered}
$$

where $j$ is ciliates, $k$ is copepods and $X_{j k}=q_{j k} Z_{j}$.

Polynomials (4th degree) were fitted to the biomass versus time for ciliates, copepods and picoplankton. Results from 8 cylinders with values for all the species/species groups were used for these calculations. Polynomials were analytically derived ([dA/d $t] / A)$. For the phytoplankton, values from Days 5 and 6 were used. The biomass for every species/species group from each of the 12 independent cylinders at each specific occasion was used to evaluate $\mu$ and $q$ according to a multiple regression model. The intercept with the $y$-axis then represents $\mu$ (the growth rate of the algae in the absence of grazers, $Z=0$ ) and the slope represents $q$. $X$, i.e. the biomass-specific zooplankton ingestion rate, is calculated by multiplying $q$ by mean algal biomass from the 12 independent cylinders on the respective day.

Since direct effects, such as ingestion, and indirect effects, such as stimulation of growth through regeneration of nutrients, cannot be separated from each other in our approach, $X$ should be interpreted as the total ecological connection between the groups of organisms. Only if mechanisms other than grazing can be neglected, then $q$ is clearance rate and $X$ is ingestion rate. The terms $q$ and $X$ are non-linearly dependent on, e.g. $A$ in addition to several other factors.

The rate coefficients $\mu, q$ and $X$ are usually not constant during an experiment; here they are represented by mean values. The coefficients can of course also differ between different experiments depending on environmental conditions and the species composition of the plankton community.
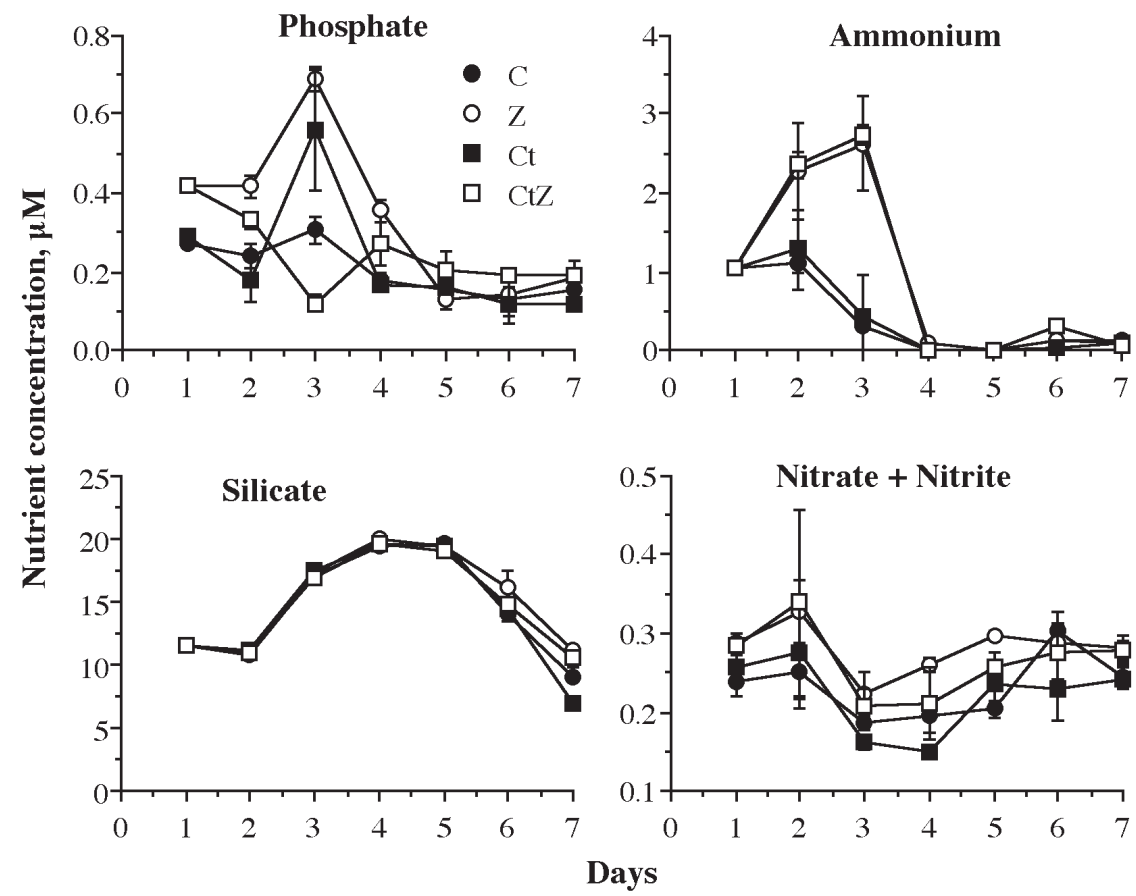

Fig. 1. Concentrations of inorganic nutrients $(\mu \mathrm{M})$, mean \pm standard deviation $(\mathrm{SD})(\mathrm{n}=3)$. C: Control; Ct: Ctenophores; CtZ: Ctenophores $+10 \times$ zooplankton; Z: $10 \times$ zooplankton

\section{RESULTS}

\section{Nutrients}

Initial concentrations of phosphate were between 0.27 and $0.41 \mu \mathrm{M}$ with the higher values in $\mathrm{Z}$ and $\mathrm{CtZ}$ cylinders. After an increase on Day 3, the concentrations in all treatments dropped to between 0.15 and $0.25 \mu \mathrm{M}$ (Fig. 1).

Ammonia increased from $1 \mu \mathrm{M}$ to $3 \mu \mathrm{M}$ from Day 1 to Day 3 in $\mathrm{Z}$ and CtZ cylinders, while in $\mathrm{C}$ and $\mathrm{Ct}$ cylinders ammonia concentrations decreased during this period. After Day 4, ammonia concentrations were at the detection limit in all treatments (Fig. 1).

Nitrate + nitrite concentrations varied around 0.25 to $0.30 \mu \mathrm{M}$ initially and increased slightly in $\mathrm{Z}$ and $\mathrm{CtZ}$ cylinders by Day 2. After a decrease on Day 3, nitrate + nitrite increased slowly during the rest of the experimental period in all treatments to about $0.32 \mu \mathrm{M}$ (Fig. 1). 
Silicate concentrations were around $11 \mu \mathrm{M}$ initially and increased in all treatments to reach a maximum on Day 4 (approximately $20 \mu \mathrm{M}$ ). Thereafter, concentrations decreased simultaneously in all cylinders to final values around $11 \mu \mathrm{M}$ in $\mathrm{Z}$ and CtZ cylinders and around $8 \mu \mathrm{M}$ in $\mathrm{C}$ and $\mathrm{Ct}$ cylinders (Fig. 1).

\section{Mesozooplankton}

At the beginning of the experiment, the mesozooplankton community was dominated by the cladocerans Evadne nordmanni and Podon polyphemoides, and the copepods Acartia clausi, Centropages hamatus, Pseudocalanus minutus and Oithona similis.
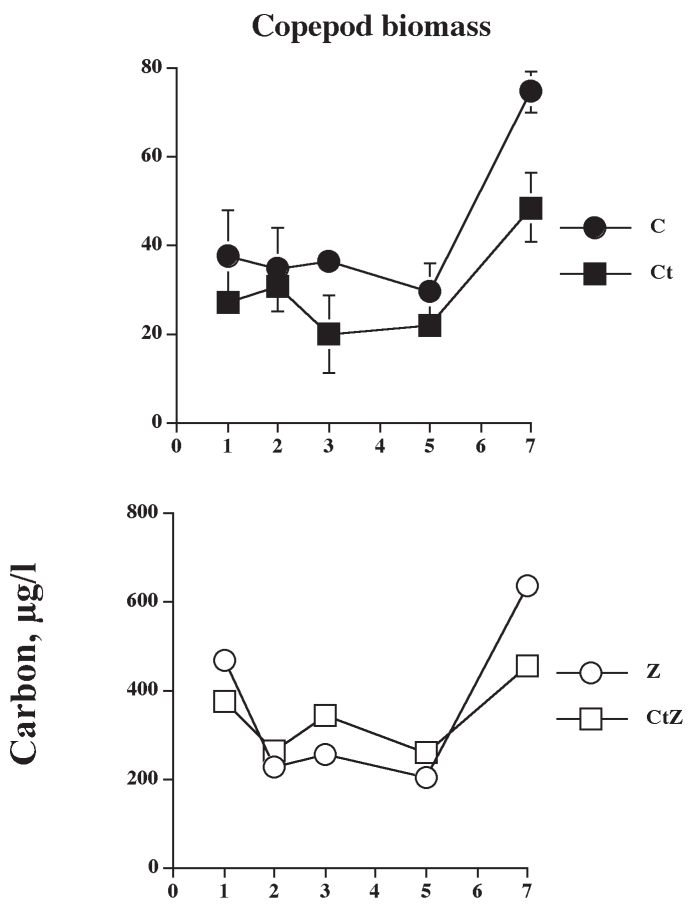

Cladoceran biomass

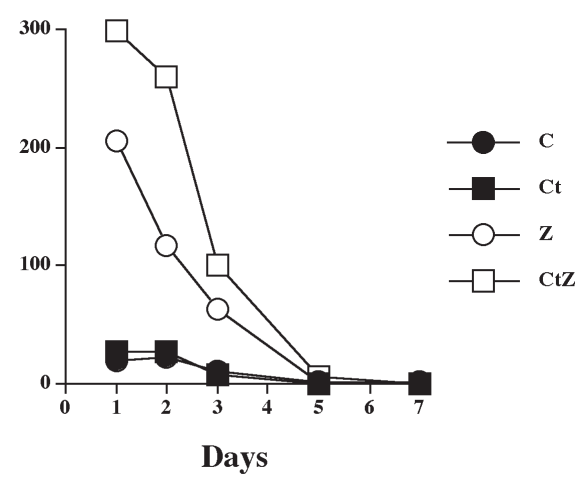

Fig. 2. Zooplankton, copepod and cladoceran, biomass carbon $\left(\mu \mathrm{g} \mathrm{l}^{-1}\right)$, mean $\pm \mathrm{SD}(\mathrm{n}=3)$. Note different scales. See Fig. 1 for treatment abbreviations
At the beginning of the experiment, the biomass of mesozooplankton was about 12.5 times higher in Z cylinders than in $\mathrm{C}$ cylinders (note differences of scale on abcissas in Fig. 2, upper and middle), while it was only 8.5 times higher at the end of the experiment. Nauplii abundance and biomass increased during the experiment in all treatments (not shown), indicating that copepods were reproductive throughout the experiment. The abundance and biomass of the cladocerans declined rapidly in all cylinders (Fig. 2).

The copepod biomass declined slightly from Day 1 to Day 2 in cylinders with zooplankton addition $(\mathrm{Z}$, CtZ), but levels were similar in treatments with and without ctenophores (Fig. 2, upper and middle). During Days 5 to 7 of the experimental period, the abundance and biomass of copepods increased in all treatments (Fig. 2, upper and middle). Centropages hamatus was the dominant species in terms of biomass, while Oithona similis was the most numerous copepod.

Mesocosms with addition of ctenophores $(\mathrm{Ct}$ and $\mathrm{CtZ}$ ) had significantly lower copepod biomass ( $\mathrm{p}<0.05$, Mann-Whitney test) on the last day of the experiment than in the $\mathrm{C}$ and $\mathrm{Z}$ cylinders. However, no significant differences were found for the first $6 \mathrm{~d}$ of the experiment ( $\mathrm{p}>0.05$, Mann-Whitney test).

Ctenophores were observed actively swimming throughout the experiment. On the last day selected ctenophores were dipped from the surfaces of mesocosms, and diameters were remeasured. Diameters were not appreciably different from the $2 \mathrm{~cm}$ initial values. When water from mesocosms was drained through $200 \mu \mathrm{m}$ mesh in an attempt to capture and count ctenophores, most exploded due to turbulence and net damage into a coagulated mass of ctenophore tissue caught on the net, precluding counts of remaining live ctenophores.

\section{Ciliates}

An initial sample that was taken directly from the fjord at the pumping site contained 4208 ciliates $\mathrm{l}^{-1}$. Most of these were oligotrichs (>95\% of total ciliate carbon), with few tintinnids, mainly Heliocostomella subulata. Throughout the experiment, the oligotrich ciliates were dominated by Strombidium emergens $(25 \times 19 \mu \mathrm{m})$ and a smaller Strombidium sp. $(19 \times$ $15 \mu \mathrm{m})$. Lower numbers of Lohmaniella sp., Urotricha sp., Tiarina fusus and the autotrophic Mesodinium rubrum were also found.

In general, simulations suggested exponential growth for ciliates in the $\mathrm{C}$ and $\mathrm{Ct}$ cylinders, with the main increase in biomass occurring between Days 3 and 6 ( $\mu=1.1$ for $C$ and 1.3 for Ct cylinders; Fig. 3 top). 


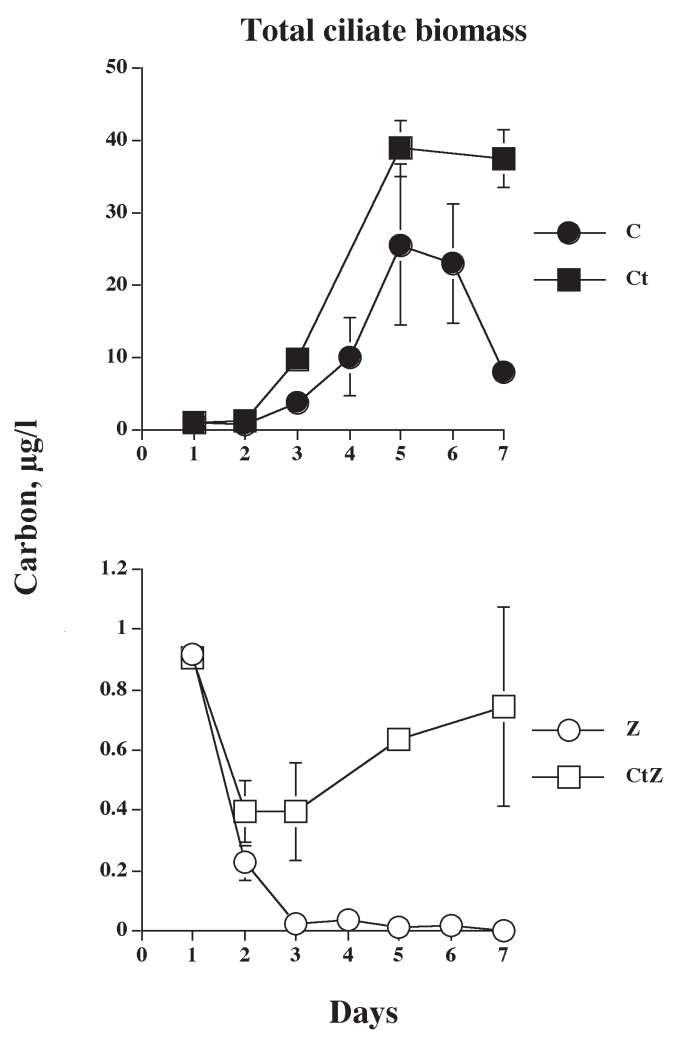

Fig. 3. Total ciliate biomass carbon $\left(\mu \mathrm{g} \mathrm{l}^{-1}\right)$, mean $\pm \operatorname{SD}(\mathrm{n}=3)$. Note different scales. See Fig. 1 for treatment abbreviations

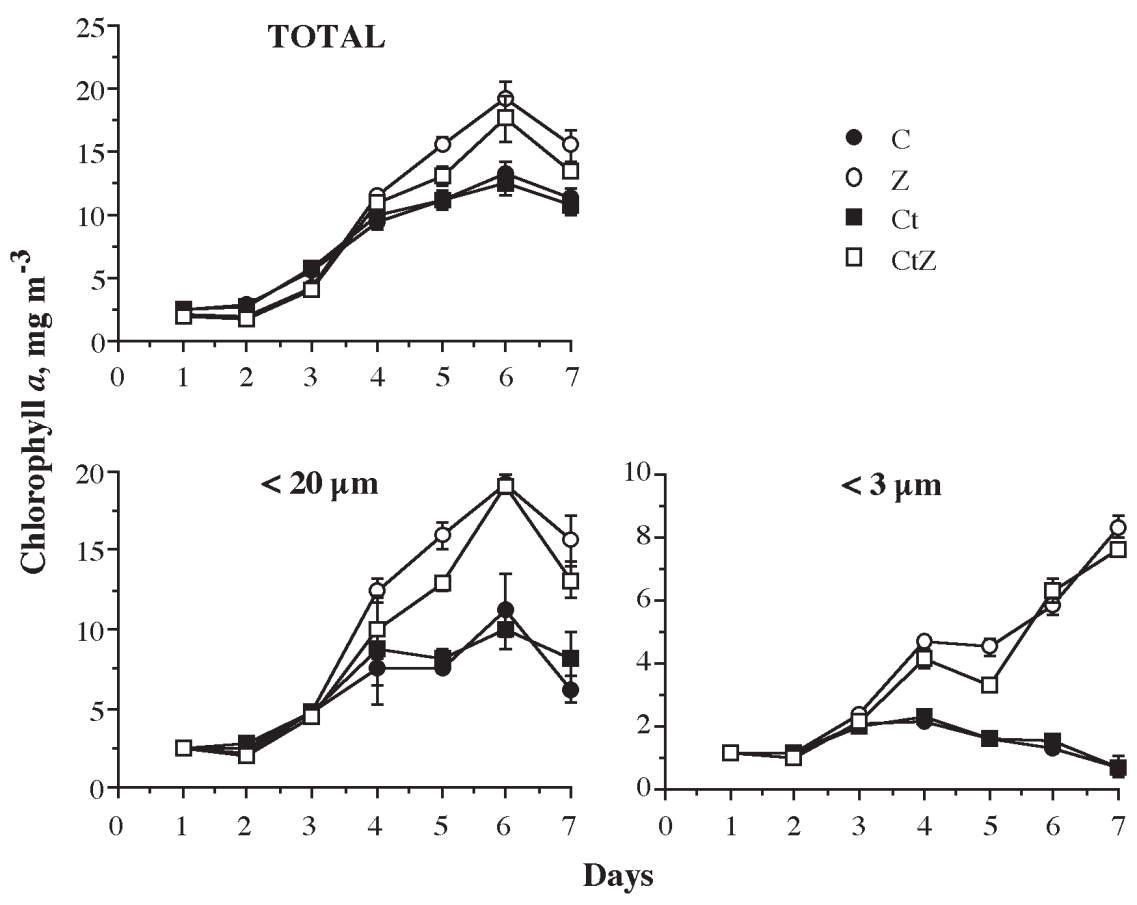

Fig. 4. Changes in chlorophyll a concentration $\left(\mathrm{mg} \mathrm{m}^{-3)}\right.$, mean $\pm \mathrm{SD}(\mathrm{n}=3)$. Values are given for whole water and the fractions $<20 \mu \mathrm{m}$ and $<3 \mu \mathrm{m}$. See Fig. 1 for treatment abbreviations
It appears that ciliates were being heavily cropped by copepods, particularly in the absence of predation on copepods by ctenophores. The measured ciliate biomass was higher in $\mathrm{Ct}$ and $\mathrm{C}$ cylinders that had natural concentrations of zooplankton but did not have zooplankton added at $10 \times$ natural concentrations (Fig. 2 top). In the cylinders with zooplankton added at $10 \times$ the natural concentrations ( $\mathrm{Z}$ and $\mathrm{CtZ}$ ), ciliate abundance was significantly lower than in $\mathrm{C}$ and $\mathrm{Ct}$, respectively ( $\mathrm{p}<0.05$, Mann Whitney test) (note differences in scales on abcissas in Fig. 3, top versus bottom). Further, in Z cylinders, ciliate abundance decreased from an initial value of 4208 ciliates $\mathrm{l}^{-1}$ to 18 ciliates $\mathrm{l}^{-1}$, and ciliate biomass was drastically lower in the $\mathrm{Z}$ than the CtZ cylinders (Fig. 3, bottom). The suggestion that predation by ctenophores on copepods decreased copepod predation on ciliates in the $\mathrm{Ct}$ and $\mathrm{CtZ}$ compared to $\mathrm{C}$ and $\mathrm{Z}$ cylinders, respectively, is supported by a significant increase in ciliate biomass in $\mathrm{Ct}$ and $\mathrm{CtZ}$, and the dramatic decline in ciliate biomass in $\mathrm{Z}$ throughout the experiment ( $p<0.01,2$-factor ANOVA).

\section{Chlorophyll}

The initial total chlorophyll a concentration was between 2 and $2.5 \mathrm{mg} \mathrm{m}^{-3}$ and increased with time in all treatments to reach a maximum on Day 6 (Fig. 4).

The chlorophyll a concentrations were higher in $\mathrm{Z}$ and $\mathrm{CtZ}$ treatments than in $\mathrm{C}$ and $\mathrm{Ct}$ treatments from Day 4 ( $p<0.05$, Mann-Whitney test; Fig. 4). This reveals that zooplankton grazing was ineffective in controlling overall phytoplankton biomass and suggests that nitrogen excreted by the higher numbers of copepods may have had a fertilizing effect on the phytoplankton biomass in these treatments. A similar, but even stronger, pattern was observed in the $<20 \mu \mathrm{m}$ and $<3 \mu \mathrm{m}$ fractions with higher concentrations in $\mathrm{Z}$ and CtZ treatments ( $\mathrm{p}<0.05$, Mann-Whitney test). For the $<3 \mu \mathrm{m}$ fraction, however, the maximum concentration of chlorophyll a was reached on Day 7, not on Day 6 as in the other fractions. This suggests that much of the increase in total phytoplankton was due to increases in ungrazed nano- and picoplankton, in containers where copepod predation on ciliates released smaller phytoplankton from ciliate grazing pressure. 


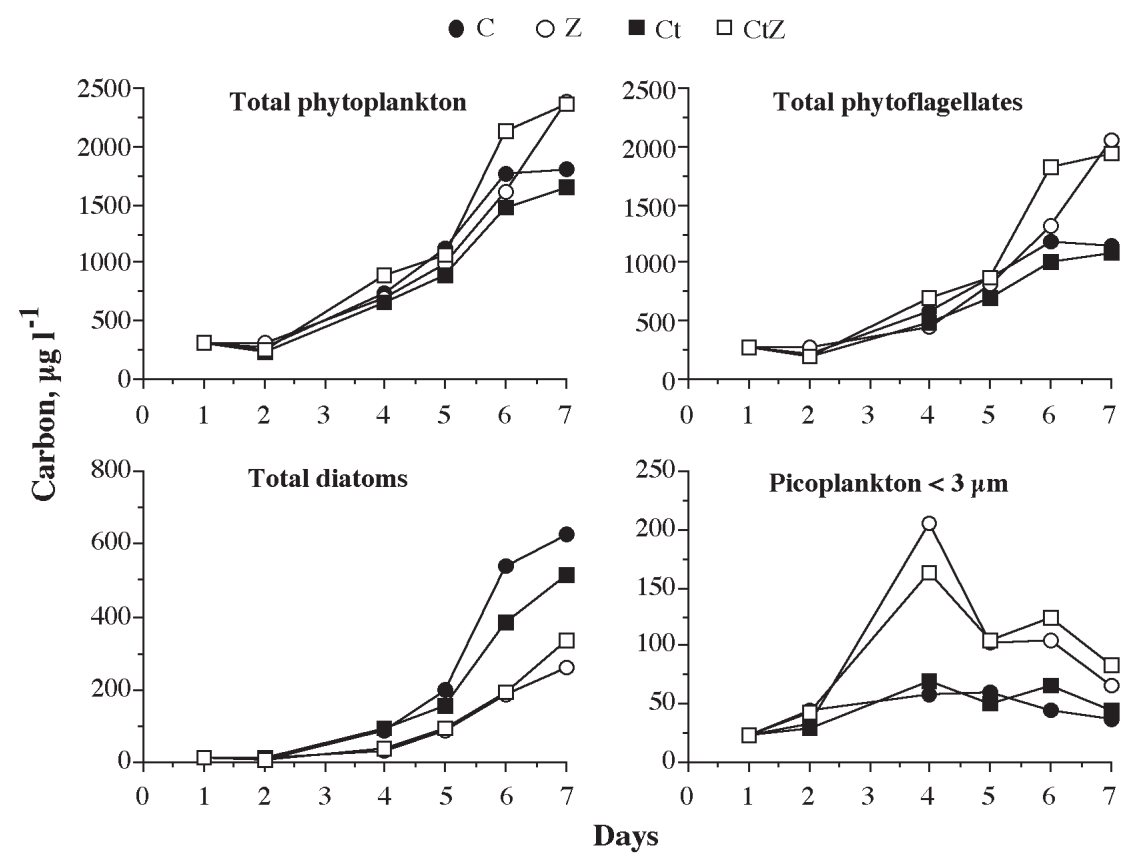

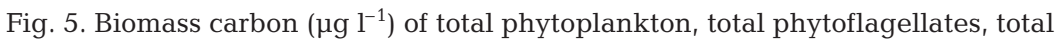
diatoms and picoplankton $(<3 \mu \mathrm{m})(\mathrm{n}=3)$. See Fig. 1 for treatment abbreviations
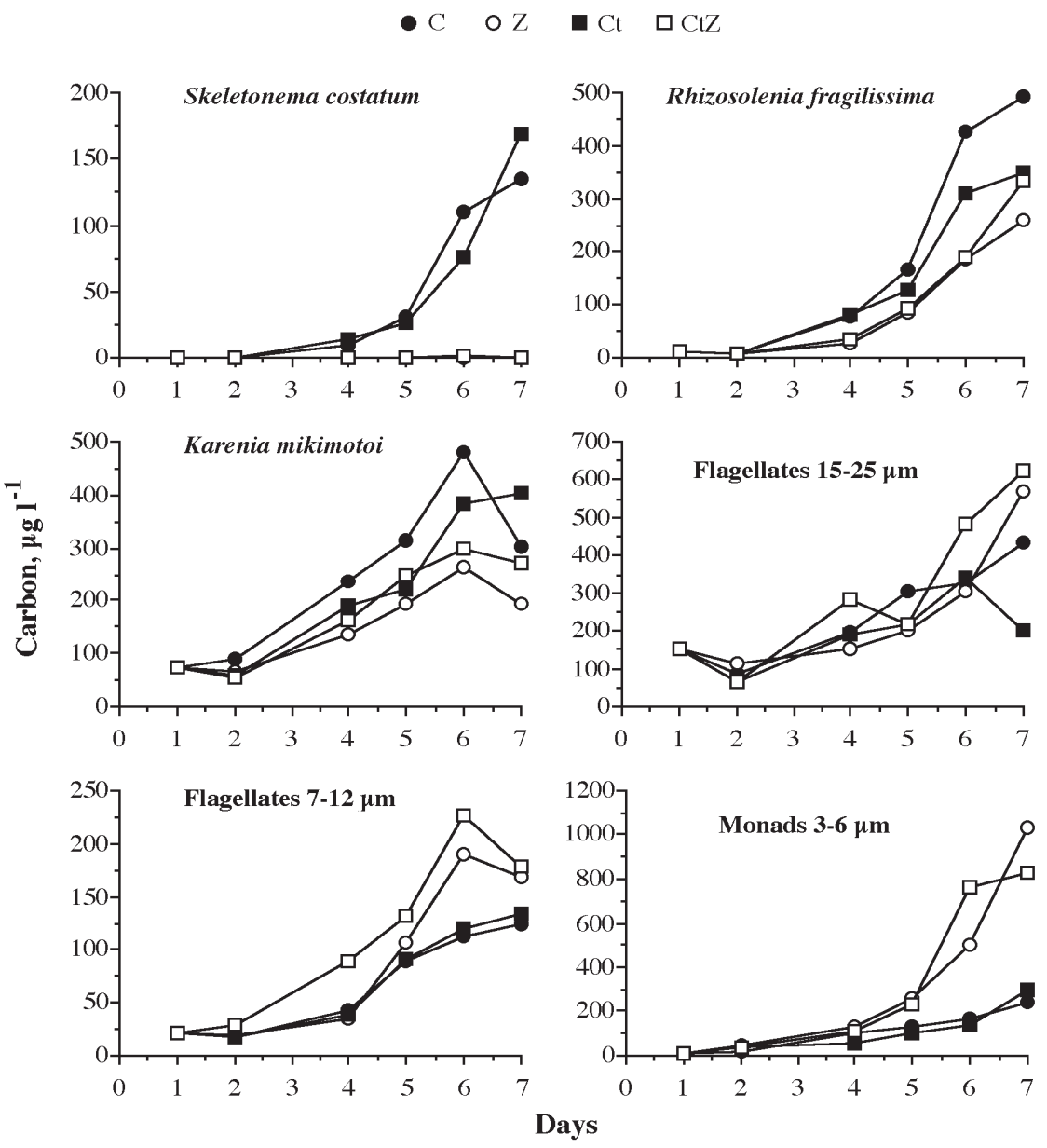

\section{Phytoplankton}

Total phytoplankton biomass (determined from microscopic counts and measurements) increased steadily in all treatments and all were similar until Day 6, after which a slightly higher biomass increase was observed in $\mathrm{Z}$ and $\mathrm{CtZ}$ cylinders than in $\mathrm{C}$ and $\mathrm{Ct}$ cylinders. Calculated values of $\mu$ for total phytoplankton were between 0.43 and 0.60 for all treatments (Day 4 to 7 ; Fig. 5). A similar pattern was observed in mesocosms for total phytoflagellate biomass, and calculated values of $\mu$ for phytoflagellates were 0.50 to 0.72 for $\mathrm{Z}$ and $\mathrm{CtZ}$, compared to 0.32 to 0.38 for $C$ and $C$, on Days 4 to 7 . All flagellated species were included here, such as the dinoflagellate Karenia sp. (12 to $15 \mu \mathrm{m})$, unidentified flagellates 15 to $25 \mu \mathrm{m}$, unidentified flagellates 7 to $12 \mu \mathrm{m}$, Chrysochromulina polylepis, Dinobryon sp., Pyramimonas sp. and monads 3 to $6 \mu \mathrm{m}$. Karenia sp. had a higher increase in $\mathrm{C}$ and $\mathrm{Ct}$ treatments than in $\mathrm{Z}$ and $\mathrm{CtZ}$ treatments, whereas in $\mathrm{Z}$ and $\mathrm{CtZ}$ cylinders other phytoflagellates between 7 and $12 \mu \mathrm{m}$ had higher biomasses than in the $\mathrm{C}$ and Ct cylinders from Day 5 ( $p<0.05$, Mann-Whitney test; Fig. 6).

The picoplankton $(<3 \mu \mathrm{m})$ biomass was higher in $\mathrm{Z}$ and $\mathrm{CtZ}$ cylinders than in $\mathrm{C}$ and $\mathrm{Ct}$ cylinders $(\mathrm{p}<0.05$, Mann-Whitney test), with a peak on Day $4\left(210 \mu \mathrm{g} \mathrm{C}^{-1}\right)$ and thereafter a decrease (Fig. 5). In $\mathrm{C}$ and $\mathrm{Ct}$ cylinders, biomass of picoplankton was low and relatively invariant (around $50 \mu \mathrm{g} \mathrm{C}^{-1}$ ) throughout the experiment (picoplankton $\mu=0.2$ to 0.6 , Days 2 to 4 ).

Diatom biomass was highest in $\mathrm{C}$ and $\mathrm{Ct}$ cylinders (Fig. 5). Growth

Fig. 6. Biomass carbon $\left(\mu \mathrm{l}^{-1}\right)$ of the diatoms Skeletonema costatum and Rhizosolenia fragilissima, the dinoflagellate Karenia sp. (K. mikimotoi), flagellates 15 to $25 \mu \mathrm{m}$, flagellates 7 to $12 \mu \mathrm{m}$ and monads 3 to $6 \mu \mathrm{m}(\mathrm{n}=3)$. See Fig. 1 for treatment abbreviations 
a)

MEASURED VALUES
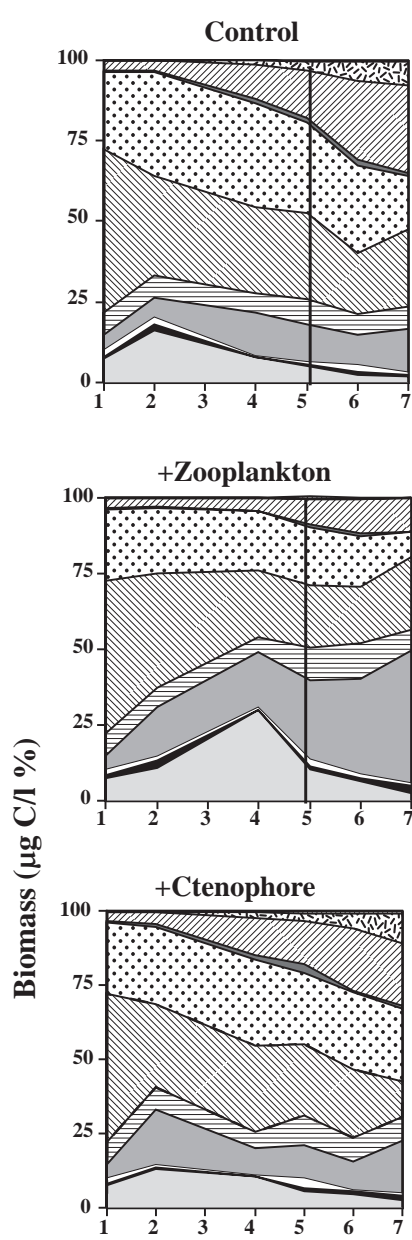

+Zooplankton and Ctenophore

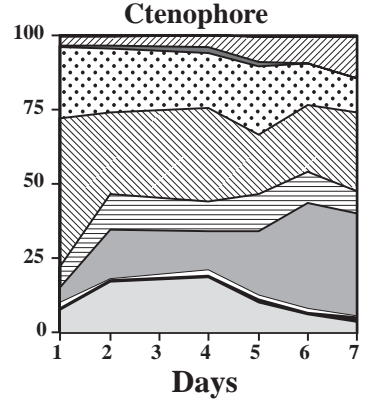

b) SIMULATED MESOCOSM
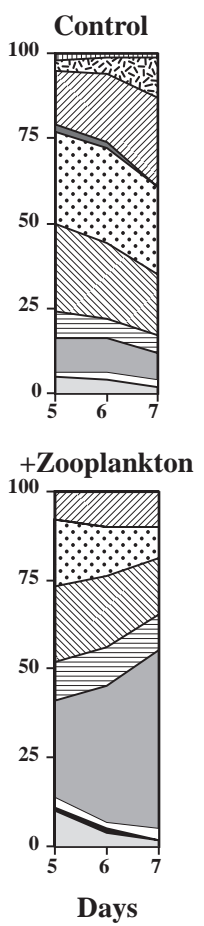

Ciliates

Skeletonema costatum

Rhizosolenia fragilissima

Dinobryon spp.

Karenia mikimotoi

Flagellates 15-25 $\mu \mathrm{m}$

Flagellates 7-12 $\mu \mathrm{m}$

Monads 3-6 $\mu \mathrm{m}$

Pyramimonas sp.

Chrysochromulina spp.

Picoplankton $<3 \mu \mathrm{m}$

Fig. 7. Relative biomass carbon $\left(\mu \mathrm{g}^{-1}\right)$ for ciliates and phytoplankton (a) measured values and (b) simulation from values measured on Day 5 of the experiment and based on Table 1 with $\alpha=0.08$ and $q=0.0032$ for copepods on ciliates $(\mathrm{n}=12)$

rates were between 0.8 and 1.1 for all treatments. Rhizosolenia fragilissima dominated with higher biomass in $\mathrm{C}$ and $\mathrm{Ct}$ cylinders than in $\mathrm{Z}$ and $\mathrm{CtZ}$ cylinders on Days 5 to 6 ( $p<0.05$, Mann-Whitney test; Fig. 6). Skeletonema costatum developed only in $\mathrm{C}$ and $\mathrm{Ct}$ treatments, apparently being completely grazed down

by the higher mesozooplankton abundance in $\mathrm{Z}$ and CtZ cylinders ( $p<0.05$, Mann-Whitney test; Fig. 6 ).

Flagellates between 15 and $25 \mu \mathrm{m}$ dominated the phytoplankton biomass in all treatments (Fig. 7). The most obvious differences between cylinders with zooplankton additions ( $\mathrm{Z}$ and $\mathrm{CtZ}$ ) and cylinders without added zooplankton (C and Ct) were the loss of Skeletonema costatum, the increase of 3 to $6 \mu \mathrm{m}$ monads and the disappearance of ciliates after zooplankton additions.

\section{Model}

Growth rates of various components of the phytoplankton, and clearance rate $(q)$ and ingestion rate $(X)$ both for ciliates and copepods grazing on phytoplankton were calculated from the model (Table 1). Rates for copepods include nauplii, which were abundant throughout the experiment. Skeletonema costatum was excluded since this species was found in only 5 cylinders.

The relative biomass distributions for different categories of phytoplankton and ciliates were simulated from values measured on Day 5 and based on Table 1 with $\alpha=0.08$ and $q=0.0032$ for copepods grazing on ciliates (Fig. 7). Measured and simulated levels of biomass for the various categories for Days 5 to 7 were in good agreement (Fig. 7).

Simulations suggested that ciliates were heavily preyed upon by copepods, and $q$ was found to be significantly higher than 0 on 5 of $7 \mathrm{~d}$ of the experimental period ( $t$-test, 1 tail, $\mathrm{p}<0.05$ Mann-Whitney test; Fig. 8).

According to the model, ciliates grazed all but the largest $(<15$ to $25 \mu \mathrm{m})$ flagellates. An attempt was made to calculate the proportion of the total carbon taken up by the ciliates that support growth $(\alpha)$ according to Eq. (2). Only values of $X>0$ were used and this gave a value of 8.1 to $14.3 \%$ of total carbon ingested.

\section{DISCUSSION}

Ctenophore predation caused a cascade of top-down effects on phytoplankton abundance and species composition. Although copepod biomass levels in treatments with and without added Pleurobrachia pileus were not significantly different except for the last day of the experiment, it appeared that ctenophore predation diminished copepod abundance or slowed copepod growth enough to reduce copepod predation pressure on ciliates, themselves the major grazers of smaller phytoflagellates. In mesocosms with natural copepod abundances, ctenophore predation contributed to increased ciliate biomass by removal of copepods. 


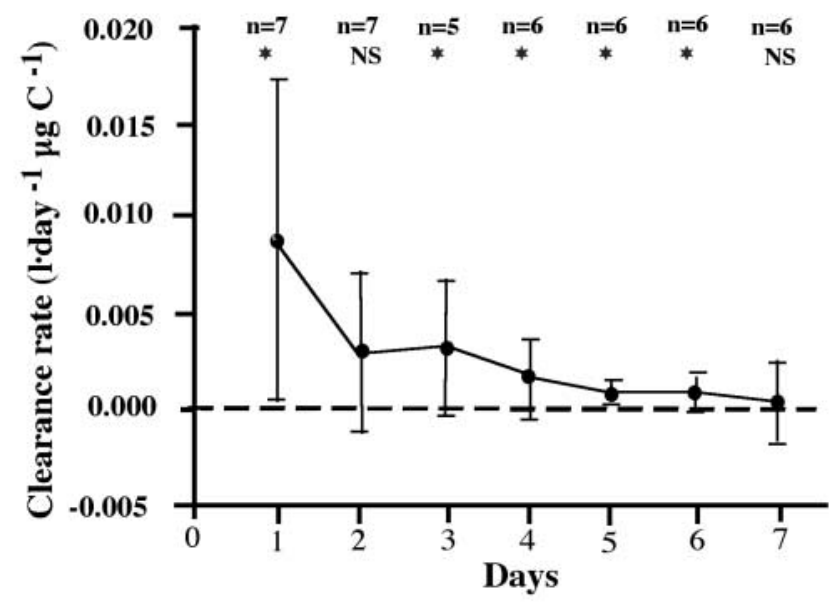

Fig. 8. Copepod grazing on ciliates expressed as clearance rate, $q\left(\mathrm{l} \mathrm{d}^{-1} \mu \mathrm{g} \mathrm{C}^{-1}\right){ }^{*}=q$ significantly $>0(\mathrm{p}<0.05)$. NS: not significant; error bars: $95 \%$ confidence interval

Resultant ciliate increases led to reductions in phytoflagellates due to ciliate grazing. These effects were particularly magnified in mesocosms with added zooplankton (primarily copepods) at $10 \times$ the natural abundance. There, copepod predation decimated ciliate biomass, in both the presence and absence of ctenophores. Differences in ciliate biomass in the presence versus absence of ctenophores in these enclosures (Fig. 3 bottom) were minor compared to differences in ciliate biomass in mesocosms without added zooplankton (Fig. 3 top; note differences in scale). This was because copepods were dramatically effective in removing ciliates. Consequently, small phytoflagellates and monads actually increased in mesocosms with added zooplankton (mainly copepods) at $10 \times$ the natural concentrations, either with or without ctenophores.

A possible reason for the low ctenophore impact on the copepod biomass may be that the concentration of ctenophores that we added (i.e. 10 ctenophores per
$300 \mathrm{l}$ cylinder, or $33 \mathrm{~m}^{-3}$ ) was too low to have significant impact. Low predation on small zooplankton species by Pleurobrachia pileus has been measured in Dutch coastal waters by Kuipers et al. (1990), at ctenophore abundance levels of 10 to $20 \mathrm{~m}^{-3}$.

The low ctenophore impact on copepod biomass might also be because Pleurobrachia sp. population growth rates were low, and our experiment did not last long enough to allow full ctenophore impact to develop. Hirota (1974) found that the rate of population growth of Pleurobrachia bachei was $0.02 \mathrm{~d}^{-1}$, which would enable the population to double in only about $35 \mathrm{~d}$, which is quite low. Since our experiments began with 10 ctenophores cylinder ${ }^{-1}$ and lasted for only $8 \mathrm{~d}$ (timescale dictated by phytoplankton:nutrient events), the main ctenophore impact may have been just beginning toward the end of our experiment. Similarly, in large enclosures (1335 $\mathrm{m}^{3}$ ) (Harris et al. 1982), heavy population predation impact by $P$. pileus did not begin until 25 d into a 40 d experiment, after several cohorts of ctenophore reproduction.

The implication that copepods in our mesocosms were substantial predators on ciliates and grazers on the diatom Skeletonema costatum was supported by independent grazing experiments performed in parallel with the mesocosm studies described here (Turner \& Granéli 1992). In the grazing experiments, Acartia clausi grazed $S$. costatum and was predatory on ciliates, whereas Centropages hamatus fed only upon ciliates. These experimental results match our mesocosm observations that there were practically no $S$. costatum ever and no ciliates present after $3 \mathrm{~d}$ in the mesocosms with added zooplankton. Similarly, Olsson et al. (1992) and Nejstgaard et al. (1997) found that copepods preferred eating ciliates to most phytoplankters in mesocosm experiments. Other studies on the importance of ciliates as a food source for copepods have been reviewed by Turner \& Roff (1993) and Levinsen et al. (2000), and references therein.

Table 1. Calculated plankton growth rates $(\mu)$, clearance rates $(q)$ and ingestion rates $(X)$ for ciliates and copepods on Day 6 . Values are based on 12 cylinders $\pm 95 \%$ confidence interval. A: plankton biomass; NS: not significant

\begin{tabular}{|c|c|c|c|c|c|c|c|c|}
\hline Day 6 & $\mu$ & $\begin{array}{c}q \\
\text { Ciliates } \\
\left(\mathrm{l} \mathrm{d}^{-1} \mu g \mathrm{C}^{-1}\right)\end{array}$ & $\begin{array}{c}q \\
\text { Copepods + nauplii } \\
\left(\operatorname{ld}^{-1} \mu \mathrm{g} \mathrm{C}^{-1}\right)\end{array}$ & No. & $\begin{array}{l}\text { ANOVA } \\
\text { 1-tailed } p\end{array}$ & $\begin{array}{c}\text { Mean } \\
(A) \\
\left(\mu g \mathrm{Cl}^{-1}\right)\end{array}$ & $\begin{array}{c}X \\
\text { Ciliates } \\
\left(\mathrm{d}^{-1}\right)\end{array}$ & $\begin{array}{c}X \\
\text { Copepods } \\
+ \text { nauplii }\left(\mathrm{d}^{-1}\right)\end{array}$ \\
\hline Flagellates 15 to $25 \mu \mathrm{m}$ & 0.07 & $-0.0092 \pm 0.0200$ & $-0.0016 \pm 0.0033$ & 8 & NS & 355 & $-3.26 \pm 7.12$ & $-0.60 \pm 1.16$ \\
\hline Flagellates 7 to $12 \mu \mathrm{m}$ & 0.28 & $0.0011 \pm 0.0040$ & $-0.0013 \pm 0.0006$ & 8 & $<0.001$ & 163 & $0.18 \pm 0.64$ & $-0.20 \pm 0.10$ \\
\hline Chrysochromulina sp. & 1.59 & $0.0220 \pm 0.0231$ & $0.0051 \pm 0.0038$ & 8 & $<0.05$ & 16 & $0.34 \pm 0.36$ & $0.08 \pm 0.06$ \\
\hline Pyramimonas sp. & 1.81 & $0.0481 \pm 0.0682$ & $0.0067 \pm 0.0111$ & 8 & NS & 24 & $1.15 \pm 1.63$ & $0.16 \pm 0.27$ \\
\hline Dinobryon sp. & 1.34 & $0.0404 \pm 0.0470$ & $0.0054 \pm 0.0077$ & 8 & NS & 16 & $0.64 \pm 0.75$ & $0.09 \pm 0.12$ \\
\hline Monads 3 to $6 \mu \mathrm{m}$ & 0.41 & $0.0047 \pm 0.0176$ & $-0.0022 \pm 0.0029$ & 8 & $<0.05$ & 389 & $1.85 \pm 6.85$ & $-0.90 \pm 1.12$ \\
\hline Gymnodinium sp. & 0.52 & $-0.0013 \pm 0.0082$ & $0.0013 \pm 0.0013$ & 8 & $<0.01$ & 370 & $-0.48 \pm 3.03$ & $0.48 \pm 0.49$ \\
\hline Rhizosolenia fragilissima & 0.78 & $-0.0036 \pm 0.0144$ & $0.0007 \pm 0.0024$ & 8 & NS & 286 & $-1.03 \pm 4.13$ & $0.19 \pm 0.67$ \\
\hline Picoplankton & -0.40 & $-0.0055 \pm 0.0058$ & $-0.0003 \pm 0.0010$ & 8 & $<0.05$ & 80 & $-0.44 \pm 0.47$ & $0.00 \pm 0.08$ \\
\hline ¿ Phytoplankton & 0.48 & $-0.0007 \pm 0.0077$ & $-0.0001 \pm 0.0013$ & 8 & NS & 1747 & $-1.20 \pm 13.47$ & $-0.20 \pm 2.20$ \\
\hline
\end{tabular}


It appears that ciliates rather than copepods were the major grazers on phytoflagellates, including smaller flagellates ( 7 to $12 \mu \mathrm{m})$, Chrysochromulina sp., Pyramimonas sp. and monads (3 to $6 \mu \mathrm{m}$ ). This is indicated by the model based on our data (Table 1) and by the increases in total phytoflagellates (Fig. 5 top right) in cylinders with added zooplankton ( $\mathrm{Z}$ and CtZ), which also had few ciliates (Fig. 3 bottom). The Strombidium sp. in the present experiment, which formed the dominant portion of ciliate biomass, were large (15 to $25 \mu \mathrm{m})$ and apparently grazed on small flagellates in the range 7 to $12 \mu \mathrm{m}$. This is supported by the results of the study by Bernard \& Rassoulzadegan (1990), in which a $12 \mu \mathrm{m}$ Strombidium sp. grazed most efficiently on particles around $2.5 \mu \mathrm{m}$ and stopped ingestion on particles around $11 \mu \mathrm{m}$. The larger flagellates in our mesocosms (15 to $25 \mu \mathrm{m}$ ) were probably too large to be grazed by the ciliates. However, large as well as small flagellates seem to have been important as grazers on nano- and picoplankton. This is shown in Table 1, where the summed ingestion rates for all sizes of flagellates were high, from small monads to larger flagellates such as the toxin-producing Chrysochromulina polylepis. The latter seems not to have been toxic at the time of our experiment, since ciliates could graze upon it, which was not the case in 1988, when a toxic bloom of this species deterred grazing by copepods and ciliates (Maestrini \& Granéli 1991). The high copepod predation on ciliates allowed total phytoplankton and total phytoflagellates to increase in all 4 treatments (Fig. 5). This resulted in an inverse flagellate-picoplankton relationship, since low abundance of picoplankton $(<3 \mu \mathrm{m})$ in $\mathrm{C}$ and $\mathrm{Ct}$, compared to $\mathrm{Z}$ and CtZ (Fig. 5), indicated that flagellates 7 to $12 \mu \mathrm{m}$ consumed picoplankton.

In grazing experiments performed simultaneously with this microcosm study, there was low grazing by copepods and cladocerans on phytoplankton, and ciliates appeared to be the dominant grazers (Turner \& Granéli 1992). Ciliates may even compete with copepods for consumption of prey $>4 \mu \mathrm{m}$ (Rassoulzadegan et al. 1988). In lakes, Carrick et al. (1991) observed a coupling of picoplankton to higher trophic levels via a picoplankton-flagellate-zooplankton link. For the food chains in our mesocosms, ciliates apparently acted as a similar link by preying upon flagellates and being preyed upon by mesozooplankton (copepods).

High copepod biomass in the cylinders with added zooplankton ( $\mathrm{Z}$ and $\mathrm{CtZ}$ ) unexpectedly resulted in higher total phytoplankton biomass levels than in cylinders with lower biomass of copepods ( $\mathrm{C}$ and $\mathrm{Ct}$ ). The difference was especially pronounced for phytoflagellate biomass. While the ciliates appear to have been exten- sively consumed by copepods, it appears that flagellates were not. This was confirmed by independent experiments of Turner \& Granéli (1992). The high copepod grazing on diatoms and predation on ciliates released the phytoflagellates from copepod grazing pressure. Also, nutrients excreted from added zooplankton and ctenophores may have contributed to maintaining high phytoplankton biomass in these treatments. That our nutrient additions did not totally neutralize effects of nutrients excreted by zooplankton and ctenophores can be inferred from levels of phosphate that never dropped below $0.2 \mu \mathrm{M}$ in these treatments. Also, increases in nitrite and nitrate suggested mineralization of excreted ammonium from zooplankton and ctenophores. Such nutrient enrichment from zooplankton excretion in mesocosms has been recorded previously (Granéli et al. 1999).

The increase in ungrazed phytoflagellates in the presence of abundant copepods was similar to mesocosm experiments from the Adriatic (Turner et al. 1999), where phytoflagellate growth proceeded relentlessly until terminated by nutrient depletion (Granéli et al. 1999). This suggests that trophic transfer from phytoplankton communities dominated by flagellates through copepods to higher consumers may be inefficient, ultimately leading to a limited production of fish (Legendre 1990).

Our original hypothesis that ctenophore predation might contribute to blooms of non-diatoms (i.e. phytoflagellates) by removing copepods that are selective feeders on diatoms was not upheld. Although copepods quickly grazed down Skeletonema costatum in enclosures and feeding experiments, this was a sideshow. The primary copepod trophic interaction was predation on ciliates, and ciliate grazing on phytoflagellates was a major determinant of phytoplankton abundance and composition. Copepod grazing was ineffective in controlling phytoflagellate abundance. Most larger dinoflagellates and phytoflagellates (which include most nuisance algal bloom taxa in the Skagerrak) were unaffected by copepod grazing and ctenophore predation. Thus, either direct or indirect topdown influences on harmful algal blooms appear to be minimal in this region. Similar conclusions resulted from mesocosm studies in this region examining the effects of top-down predation by fish (Granéli et al. 1993).

Since Chrysochromulina polylepis, the flagellate that caused the 1988 toxic bloom in the Skagerrak, is only $10 \mu \mathrm{m}$ in size, our results suggest that it would likely be grazed primarily by ciliates rather than copepods. Thus, ctenophore predation on copepods would likely reduce copepod predation pressure on ciliates, thereby reducing ciliate grazing pressure on Chrysochromulina sp. 
Acknowledgements. We wish to thank Wilhelm Granéli (University of Lund) for comments and suggestions on the manuscript, and we are indebted to Per Olsson, Michael Fryd, Ole Henrik Haslund and Eva Schöllhorn (all formerly of the University of Lund) for providing some of their unpublished data, and Christer Nylander and Christina Esplund-Lindquist for technical assistance. This work was supported by grants from The Swedish Science Research Council (VR), and The Carl Triguers and Crafoord Foundations. Edna Granéli's salary (in 1990) was provided by The Swedish Forestry and Agriculture Research Council. We appreciate the hospitality of the staff of the Kristineberg Marine Biological Laboratory, Professor J.-O. Stromberg, Director, during our stay. We thank the University of Kalmar for present support of E.G. and for assuming travel expenses for J.T.T. to complete the writing of this paper.

\section{LITERATURE CITED}

Båmstedt U (1998) Trophodynamics of Pleurobrachia pileus (Ctenophora, Cydippida) and ctenophore summer occurrence off the Norwegian north-west coast. Sarsia 83: 169-181

Bernard C, Rassoulzadegan F (1990) Bacteria or microflagellates as a major food source for marine ciliates: possible implications for the microzooplankton. Mar Ecol Prog Ser 64:147-155

Carpenter SR (ed) (1988) Complex interactions in lake communities. Springer-Verlag, New York

Carpenter SR, Kitchell JF, Hodgson JR (1985) Cascading trophic interactions and lake productivity. BioScience 35: 634-639

Carrick HJ, Fahnenstiel GL, Stoermer EF, Wetzel RG (1991) The importance of zooplankton-protozoan trophic couplings in Lake Michigan. Limnol Oceanogr 36:1335-1345

Coats DW, Heinbokel JF (1982) A study of reproduction and other life cycle phenomena in planktonic protists using an acridine orange fluorescence technique. Mar Biol 67:71-79

Dahl E, Lindahl O, Paasche E, Throndsen J (1989) The Chrysochromulina polylepis bloom in Scandinavian waters during spring 1988. In: Cosper EM, Bricelj VM, Carpenter EJ (eds) Novel phytoplankton blooms: causes and impacts of recurrent brown tides and other unusual blooms. Coastal and Estuarine Studies 35. Springer-Verlag, Berlin, p 383-405

Deason EE (1982) Mnemiopsis leidyi (Ctenophora) in Narragansett Bay, 1975-1979: abundance, size composition and estimation of grazing. Estuar Coast Shelf Sci 15:121-134

Deason EE, Smayda TJ (1982) Ctenophore-zooplanktonphytoplankton interactions in Narragansett Bay, Rhode Island, USA, during 1972-1977. J Plankton Res 4:203-217

Edler L (1979) Baltic marine biologists: recommendations for marine biological studies in the Baltic Sea-phytoplankton and chlorophyll. BMB Publ 5. (Copies available from the Department of Marine Ecology, University of Lund, 22100 Lund, Sweden)

Fenchel T, Finlay BJ (1983) Respiration rates in heterotrophic freeliving protozoa. Microb Ecol 9:99-122

Frank KT (1986) Ecological significance of the ctenophore Pleurobrachia pileus off southwestern Nova Scotia. Can J Fish Aquat Sci 43:211-222

French DP, Smayda TJ (1995) Temperature regulated responses of nitrogen limited Heterosigma akashiwo, with relevance to its blooms. In: Lassus $\mathrm{P}$, Arzul G, Erard E, Gentien P, Marcaillou C (eds) Harmful algal blooms. Lavoisier, Paris, p 585-590

Granéli E, Carlsson P, Olsson P, Sundström B, Granéli W, Lin- dahl O (1989) From anoxia to fish poisoning: the last ten years of phytoplankton blooms in Swedish marine waters. In: Cosper EM, Bricelj VM, Carpenter EJ (eds) Novel phytoplankton blooms: causes and impacts of recurrent brown tides and other unusual blooms. Coastal and Estuarine Studies 35. Springer-Verlag, Berlin, p 407-427

Granéli EP, Olsson P, Carlsson P, Granéli W, Nylander C (1993) Weak 'top-down' control of dinoflagellate growth in the coastal Skagerrak. J Plankton Res 15:213-237

Granéli E, Carlsson P, Turner JT, Tester PA, Béchemin C, Dawson, R, Funari E (1999) Effects of N:P:Si ratios and zooplankton grazing on phytoplankton communities in the northern Adriatic Sea. I. Nutrients, phytoplankton biomass, and polysaccharide production. Aquat Microb Ecol $18: 37-54$

Greve W, Reiners F (1988) Plankton time-space dynamics in German Bight: a system approach. Oecologia 77:487-496

Harris RP, Reeve MR, Grice GD, Evans GT, Gibson VR, Beers JR, Sullivan BK (1982) Trophic interactions and production processes in natural zooplankton communities in enclosed water columns. In: Grice GD, Reeve MR (eds) Marine mesocosms: biological and chemical research in experimental ecosystems. Springer-Verlag, New York, p 353-387

Hernroth L (1985) Baltic marine biologists: recommendations on methods for marine biological studies in the Baltic Sea - mesozooplankton biomass assessment. BMB Publ 10 (Copies available from Kristinebergs Marine Biological Station, 45034 Fiskebäckskil, Sweden)

Hirota J (1974) Quantitative natural history of Pleurobrachia bachei in La Jolla Bight. Fish Bull US 72:295-335

Jeffrey SW, Humphrey GF (1975) New spectrophotometric equations for determining chlorophylls $a, b, c 1$ and $c 2$ in higher plants, algae and natural phytoplankton. Biochem Physiol Planfz 167:191-194

Kankaala P, Johanson S (1986) The influence of individual variation on length-biomass regressions in three crustacean zooplankton species. J Plankton Res 8:1027-1038

Klein Breteler WCM, Franz HG, Gonzalez SR (1982) Growth and development of four calanoid copepod species under experimental and natural conditions. Neth J Sea Res 16: 195-207

Kremer P (1979) Predation by the ctenophore Mnemiopsis leidyi in Narragansett Bay, Rhode Island. Estuaries 2:97-105

Kuipers BR, Gaedke U, Enserink L, Witte H (1990) Effect of ctenophore predation on mesozooplankton during an outburst of Pleurobrachia pileus. Neth J Sea Res 26:111-124

Lampitt R (1979) Aspects of the nutritional ecology of the marine planktonic copepod Oithona nana. PhD thesis, University of Aberdeen

Legendre L (1990) The significance of microalgal blooms for fisheries and for the export of particulate organic carbon in the oceans. J Plankton Res 12:681-699

Lehman JT, Sandgren CD (1985). Species-specific rates of growth and grazing loss among freshwater algae. Limnol Oceanogr 30:34-46

Levinsen H, Turner JT, Nielsen TG, Hansen BW (2000) On the trophic coupling between protists and copepods in Arctic marine ecosystems. Mar Ecol Prog Ser 204:65-77

Lindahl O, Hernroth L (1983) Phyto-zooplankton community in coastal waters of western Sweden: an ecosystem off balance? Mar Ecol Prog Ser 10:119-126

Lindahl O, Hernroth L (1988) Large-scale and long-term variations in the zooplankton community of the Gullmar fjord, Sweden, in relation to advective processes. Mar Ecol Prog Ser 43:161-171

Maestrini SY, Granéli E (1991) Environmental conditions and ecophysiological mechanisms which led to the 1988 
Chrysochromulina polylepis bloom: an hypothesis. Oceanol Acta 14:397-413

Miller RJ, Daan R (1989) Planktonic predators and copepod abundance near the Dutch coast. J Plankton Res 11: 263-282

Möller H (1980) Population dynamics of Aurelia aurita medusae in Kiel Bight, Germany (FRG). Mar Biol 60:123-128

Nejstgaard JC, Gismervik I, Solberg PT (1997) Feeding and reproduction by Calanus finmarchicus, and microzooplankton grazing during mesocosm blooms of diatoms and the coccolithophore Emiliania huxleyi. Mar Ecol Prog Ser 147:197-217

Olsson P, Granéli E, Carlsson P, Abreu P (1992) Structuring of a postspring phytoplankton community by manipulation of trophic interactions. J Exp Mar Biol Ecol 158:249-266

Rassoulzadegan F, Laval-Peuto M, Sheldon RW (1988) Partitioning of food ration of marine ciliates between pico- and nanoplankton. Hydrobiologia 159:75-88

Reeve MR, Walter MA (1978) Nutritional ecology of ctenophores: a review of recent research. Adv Mar Biol 15: 249-287

Schneider G, Behrends G (1998) Top-down control in a neritic plankton system by Aurelia aurita medusae: a summary. Ophelia 48:71-82

Turner JT, Granéli E (1992) Zooplankton feeding ecology:

Editorial responsibility: Otto Kinne (Editor),

Oldendorf/Luhe, Germany grazing during enclosure studies of phytoplankton blooms from the west coast of Sweden. J Exp Mar Biol Ecol 157: 19-31

Turner JT, Roff JC (1993) Trophic levels and trophospecies in marine plankton: lessons from the microbial food web. Mar Microb Food Webs 7:225-248

Turner JT, Tester PA (1989) Zooplankton feeding ecology: copepod grazing during an expatriate red tide. In: Cosper EM, Bricelj VM, Carpenter EJ (eds) Novel phytoplankton blooms: causes and impacts of recurrent brown tides and other unusual blooms. Coastal and Estuarine Studies 35. Springer-Verlag, Berlin, p 359-374

Turner JT, Bruno SF, Larson RJ, Staker RD, Sharma GM (1983) Seasonality of plankton assemblages in a temperate estuary. PSZN I: Mar Ecol 4:81-99

Turner JT, Tester PA, Lincoln JA, Carlsson P, Granéli E (1999) Effects of N:P:Si ratios and zooplankton grazing on phytoplankton communities in the northern Adriatic Sea. III. Zooplankton populations and grazing. Aquat Microb Ecol 18:67-75

UNESCO (1983) Chemical methods for use in marine environmental monitoring. Intergovernmental Oceanographic Commission, Manuals and Guides, No. 12, UNESCO, Paris Utermöhl H (1958) Zur Vervollkommnung der quantitativen Phytoplankton-Methodik. Verh Int Ver Limnol 9:1-38

Submitted: September 6, 2001; Accepted: March 19, 2002 Proofs received from author(s): August 9, 2002 